\title{
A Study on Effects of Soil Physico-Chemical Properties on Cocoa Production in Ondo State
}

\author{
Ololade I.A \\ Department of Chemistry and Industrial Chemistry, Adekunle Ajasin University, Akungba Akoko, Ondo State \\ Tel: 23-47-781-2009Ｅ-mail: olisa200@yahoo.com
}

Ajayi I.R

Department of Physics and Electronics, Adekunle Ajasin University, Akungba Akoko, Ondo State

Gbadamosi A.E

Department of Plant Science and Biotechnology, Adekunle Ajasin University, Akungba Akoko, Ondo State

Mohammed O.Z

Department of Geology and Geophysics, Adekunle Ajasin University, Akungba Akoko, Ondo State

Sunday A.G

Department of Physics and Electronics, Adekunle Ajasin University, Akungba Akoko, Ondo State

This study was sponsored by National Space Research and Development Agency (NASRDA), Nigeria.

\begin{abstract}
Cocoa is a major export crop in Nigeria with highest percentage coming from Ondo State. However, the production has dwindled in recent years. This study has examined the impacts of soil physico-chemical properties ( $\mathrm{pH}$, total organic carbon (TOC), cation exchange capacity (CEC) and textural nature) of different cocoa plantations within six selected communities of Ondo State, Nigeria on cocoa productivity. Results obtained showed that soils of the various locations are not significantly different from one another in terms of chemical properties but differ with decreasing soil profile. The $\mathrm{pH}, \mathrm{OC}$ and CEC obtained ranged from 5.1, 0.35 $-4.30 \%$ and $2.10-6.05 \mathrm{meq} / 100 \mathrm{~g}$ respectively which tended to decrease with depth. A guided fertilizer usage has been recommended to cocoa farmers to boost the productivity of the cash crop.
\end{abstract}

Keywords: Cocoa Farms, Soil Fertility, Cocoa Production, Cation Exchange Capacity

\section{Introduction}

Agriculture plays an important and strategic role in the revival of Nigerian national economy and cocoa (Theobroma cacao L.) remains a major export crop in Nigeria. In 1998, a revenue of 7459.3 million Naira (US\$ 53,280 at 140 per US\$) was derived from dried cocoa beans (half of the income attributed to the total export of major agricultural products) (CBN, 1998). Cocoa was first cultivated in the western region of Nigeria in 1890 (Adegeye, 1996). Its cultivation gained prominence rapidly in Nigeria such that by 1965, Nigeria became the second largest producer in the world (Adegeye, 1996).

In general, cocoa producing states lie within the rainforest zone of Nigeria which includes Ondo, Ogun, Oyo, Ekiti, Ogun, Edo, Delta, Cross-Rivers and Akwa-Ibom. However, over $50 \%$ of the total quantity of cocoa produced for export or utilized locally per annum comes from Ondo State (Adegeye, 1996). The production, however, has declined in recent years; a fact attributed partly to poor soil quality (Ajobo, 1980; Egbe, 1989).

In Nigeria, and elsewhere in the tropics, extensive studies have been carried out on many tree crops including cocoa (Ekanade 1985a, 1985b, 1988). Previous records on soil survey between 1951 and 1962, within the cocoa belts of Nigeria revealed that about $62 \%$ of Nigeria cocoa is grown on good or fairly good soils and the remaining thirty eight per cent on poor or very poor soil (Smyth and Montgonery, 1962). It has also been shown 
experimentally by the Cocoa Research Institute of Nigeria (CRIN) that continuous cultivation of cocoa at same farmland leads to appreciable decline in physico and chemical properties of the soil (Omotosho, 1965, 1971).

Crop production involves a complex interaction between the environment, soil parameters, and nutrient dynamics. Because of this fact, the soil must be studied in terms of the productive potentials. Failure to understand these complexities has resulted in lack of good crop production and management techniques; hence agricultural production has tended to be low.

Soil fertility decline is considered as an important cause for low productivity of many soils ( Sanchez, 2002). It has not received the same amount of research attention as soil erosion; probably because as soil fertility decline is less visible and less spectacular, and more difficult to assess. Assessing soil fertility decline is difficult because most soil chemical properties either change very slowly or have large seasonal fluctuations. This decline includes; nutrient depletion, nutrient mining, acidification (decline in $\mathrm{pH}$ and or an increase in exchangeable $\mathrm{Al}$ ), loss of organic matter and increase in toxic elements (e.g., Al, Mn) (Hartemink, 2006).

In the present study, physicochemical characterization of soils namely $\mathrm{pH}$, clay, silt, sand, total organic carbon (TOC) and exchangeable cations from different cocoa plantations in selected communities Ondo State, Nigeria, has been carried out at different soil depths $(0-15 \mathrm{~cm}: 15-30 \mathrm{~cm} ; 30-45 \mathrm{~cm})$. The specific objectives included (1) to make a detailed characterization of some selected cocoa soils of Ondo State and examine the impact of each parameter to cocoa yield (2) to evaluate these soils for cocoa production and (3) to identify communities of probable maximum cocoa which can be encouraged.

\subsection{Materials and Methods}

\subsubsection{Study Area}

Ondo State is the largest cocoa-producing state in Nigeria (Olujide and Adeogun, 2006). It is commonly known as the cocoa belt or the land of cocoa farmers. Out of the several cocoa producing communities in the state, soils from six communities were carefully selected in the present study. These cocoa farms are located as follows: Oda town in Akure, Government Farm in Idanre, Ago Panu in Owo, Ikpenme in Owo, Ile-Oluji farm and Bagbe in Ondo (Fig. 1). Details of the sampling locations and climatic conditions are presented in Table 1.

\subsubsection{Sampling}

A crucial issue in quantitative plant ecology is the selection of sample from which data is to be collected. This is because the reliability of the final conclusions depends largely on how well the data have been built (Kershaw, 1985). Sampling design for this study was based on two premises: first, the need to spread sample sites objectively over the study area and second, the need to ensure that plant and site characteristics are adequately depicted. The entire plantation at each community was divided into three plots from each of which samples were collected. Soil samples were collected from three sampling depths $0-15 \mathrm{~cm}, 15-30 \mathrm{~cm}$ and $30-45 \mathrm{~cm}$, hereafter referred to as topsoil, subsoil (SS) and sub-sub soil (SSS) respectively. The sampling was restricted to this zone because the zone provides the bulk of plant nutrients (Soil Survey Laboratory Staff, 1992). Samples were collected inside labeled polythene bags.

\subsubsection{Sample Treatment and Analysis}

Soil samples were air-dried, sieved, and analyzed in the laboratory using standard techniques. Particle size composition was obtained by hydrometer method (Bouyoucos, 1962). Soil pH was determined in water and 0.1 $\mathrm{M} \mathrm{KCl}$ solution at 1:2.5 soil/solution ratio. Organic carbon content was found by the modified $\mathrm{K}_{2} \mathrm{Cr}_{2} \mathrm{O}_{7}$ digestion of Walkley-Black method (Nelson and Sommers, 1996). The cation exchange capacity (CEC) was determined by adding the $1 \mathrm{M} \mathrm{KCl}$ extractable acidity to cations $\left(\mathrm{Ca}^{2+}, \mathrm{Mg}^{2+}, \mathrm{Na}^{+}, \mathrm{K}^{+}\right)$exchanged by neutral $1 \mathrm{M}$ $\mathrm{NH}_{4} \mathrm{C}_{2} \mathrm{H}_{3} \mathrm{O}_{2}$ (pH 7) as described in Thomas (1982). The $\mathrm{K}$ and Na were measured with flame photometer while the $\mathrm{Mg}$ and $\mathrm{Ca}$ were determined with atomic absorption spectrophotometer. The exchangeable acidity was determined by titration and the cation exchange capacity (CEC) was obtained by summation of exchangeable cations and exchange acidity.

\subsection{Results}

The ranges of the results of some soil physico-chemical properties of the various sampling locations are presented in Table 2 while Fig. 2 gives the textural pattern of the soils at different depths. The sand, clay and silt (\%) ranged between $65-39,40-19$ and $26-12$ respectively. At Ikpenme Farm in Owo, the mean pH at TS, SS and SSS are $7.2 \pm 0.3,6.7 \pm 0.2$ and $6.6 \pm 0.3$ respectively while the OC (\%) gave $1.6 \pm 0.2,0.9 \pm 0.1$ and $0.5 \pm 0.2$ respectively. For the CEC (meq/100g), the mean values are 5.7 $\pm 0.6,5.1 \pm 1.5$ and $6.0 \pm 0.6$ respectively. In a similar trend, at Ago Panu, the highest mean $\mathrm{pH}(6.7 \pm 0.4)$ and the least $(6.1 \pm 0.4)$ were recorded at TS and SSS 
respectively. The mean OC (\%) ranges between 1.77 (at SSS) to 0.70 (at TS) while mean levels of CEC (meq/100g) are $3.3 \pm 1.1,4.3 \pm 1.0$ and $6.1 \pm 0.9$ for the TS, SS and SSS respectively.

The trend differs at Ile - Oluji where the mean pH was 5.2(at TS) and 5.5 (at SSS). However, for OC (\%) and CEC (meq/100g), the mean concentrations decrease with depth. The highest mean OC $(1.7 \pm 0.2)$ and the least $(0.2 \pm 0.1)$ were recorded at TS and SSS respectively. Similarly mean CEC (meq/100g) values of $4.3 \pm 0.6,3.2 \pm 0.9$ and 2.6 \pm 0.5 were recorded at TS, SS and SSS respectively. At Bagbe in Ondo, all the parameters determined decreases with increasing soil depth. The highest and least mean $\mathrm{pH}$ is $6.3 \pm 0.4$ (at TS) and $5.4 \pm 0.2$ (in SSS). The mean OC from $0.9 \pm 0.4$ (in SSS) to $2.9 \pm 0.8$ (in TS) while the mean CEC (meq/100g) are $4.3 \pm 1.5,3.2 \pm 0.8$ and $2.9 \pm 0.6$ for the TS, SS and SSS respectively. The mean $\mathrm{pH}$ across the various depths in soils from Govt. Farm Idanre is very close (6.6 to 6.7). Both the $\mathrm{OC}$ and the $\mathrm{CEC}$ decrease with depth. In TS, highest mean concentration of OM $(4.0 \pm 0.3)$ and CEC $(5.2 \pm 1.2 \mathrm{meq} / 100 \mathrm{~g}))$ were recorded while the least concentration of OM $(0.6 \pm 0.2)$ and CEC $(2.1 \pm 0.3 \mathrm{meq} / 100 \mathrm{~g}))$ were recorded in SSS and SS respectively. In soils from Oda farm in Akure, the mean $\mathrm{pH}$ across the various depth ranges between 6.22 to 6.48 while the highest and the least mean OM (CEC in bracket) were $3.8 \pm 0.1(5.2 \pm 0.6 \mathrm{meq} / 100 \mathrm{~g})$ and $1.2 \pm 0.4(2.8 \pm 0.4 \mathrm{meq} / 100 \mathrm{~g}))$ in sample of TS and SS respectively.

\subsection{Discussion}

\subsubsection{Particle size analysis}

One possible confounding factor that could explain some of the variations in soil physicochemical characteristics from the various locations is difference in grain size distribution (Fig. 2). The soil contain significant percentage of sand, particularly at Bagbe, Govt. Farm Idanre, Ile-Oluji in Oda in Akure while high proportion of silt and clay were recorded at both Ago Panu and Ikpenme in Owo LG. Soils composed largely of silt and clay compress (collapse) as they lose water, leaving no air-filled interstices. Such soils continue to have low permeability to oxygen during subaerial exposure despite water loss, allowing anaerobic conditions to persist during low tide. Soils of intermediate grain size composition exhibit partial compression. Indeed, compressibility has been found to be linearly correlated to silt-clay content (Bradley and Morris, 1990). This compressibility as experienced may be responsible to the poor quality of cocoa at Ikpenme and Ago Panu.

\subsubsection{Effects of Soil $\mathrm{pH}$}

The effect of soil $\mathrm{pH}$ is profound on the solubility of minerals and nutrients. It is regarded as a useful indicator of other soil parameters. Particularly, profound yields useful information about the availabilities of exchangeable cations (e.g $\mathrm{Ca}^{2+}, \mathrm{Mg}^{2+}, \mathrm{K}^{+}$, e.t.c) in soils. Most minerals and nutrients are more soluble or available in acid soils than in neutral or slightly alkaline soils. The average $\mathrm{pH}-\mathrm{H}_{2} \mathrm{O}$ of Ago Panu, Ikpenme, Govt. Farm Idanre and Oda Akure was neutral (pH 6.0 - 7.5) based on literature (Dennis, 1993). However, the $\mathrm{pH}$ varied from slightly acid to neutral ( $\mathrm{pH} 5.5-6.0)$ for Bagbe-Ondo. Soil pH reveals that the soil is mildly acidic at Ile-Oluji Farm. This condition in soils from Bagbe and Ile-Oluji is favorable to nutrient uptake by plants (Tisdale and Nelson, 1975). This could be responsible for the relatively better quality cocoa products from these locations.

The $\mathrm{pH}$ varies slightly with depth at Bagbe, Ago-panu and Ikpenme. It is relatively stable at Government farm Idanre and Oda-Akure while at Ile-Oluji, the pH slightly decreases with depth. Several factors may be responsible for the fluctuating nature of the $\mathrm{pH}$ with depth. This may include variability in the use of fertilizer and some other chemicals and also the year of establishment.

\subsubsection{Organic Matter Assessment}

The organic matter of soils includes the remains of plants, animals and microorganisms in all stages of decomposition. The level of organic matters in soils influences a number of soil chemical and physical properties. Based on available data on soil guidelines, the data in Table 2, the OC falls within medium to high (Karageorgis, 2005). In the present study, highest OC was recorded in the TS which tend to decrease sharply the soil profile at some locations and mild at some across all the study sites (Fig 3a-c). Across all the sampling locations, the OC content of the soil decreases with depth (Fig 2a-c). This is most pronounced $(\mathrm{p}<0.05)$ between the top soil $(0-$ $15 \mathrm{~cm})$ and the sub-soil $(15-30 \mathrm{~cm})$ depth. Further decrease at depth $30-45 \mathrm{~cm}$ was not significant $(\mathrm{p}>0.05)$.

The decrease with depth occurs at different rates indicating that other factors play significant roles in organic matter decomposition. Organic carbon content of all the top soils was high $(2-5 \%)$ for Ile - Oluji, Govt. Farm Idanre, Oda Akure and Bagbe-Ondo, and medium (1-2\%) for Ago-Panu and Ikpenme both in Owo (Denis, 1993). According to Figs. 3a-c, highest percentage of OC was recorded at Government farm Idanre and Oda- Akure. However, about $75 \%$ of this content resides within the top-soil unlike Ile-Oluji farm and Bagbe where the OC content are better distributed within the various soil depths. Thus, soils from these locations displayed the most 
farmers' friendly trend in OC reduction with depth. This is good for a tree crop like cocoa, with a tap root that is deep rooted. The low organic matter content as recorded in Ikpenme and Ago Panu can be said to be contributory to the low and poor quality cocoa from these locations.

\subsubsection{Assessment of Soil CEC}

The CEC is a measure of the soil's ability to adsorb (and release) cations. It is highly needed for the estimation of contaminant transport potential and sorption capacity for any soil location i.e. the total number of cations it can retain on its adsorbent complex at a given $\mathrm{pH}$. The CEC's across the various sites ranged from 6.05 to 2.10 meq/100g. These values falls within low to very low CEC based on EPA's ESES guidelines (Russell, 1994). The presence of these low values of CEC indicates the presence of less clay and organic matter (Liber et al., 1996). The exchangeable cations occur in low to very low concentrations, with calcium being the most abundant (Table 2).

Based on the data in Table 2, even when the exchangeable $\mathrm{K}$ is assumed as available $\mathrm{K}$, the value was very low $(0.12-0.43 \mathrm{mg} / \mathrm{kg})$ for all the soil layers. Previous researcher suggested the application of potassium fertilizer to soils with exchangeable $\mathrm{K}$ of $<0.30 \mathrm{mg} / \mathrm{kg}$ fertilizer (Adiningsih and Sudjadi 1983; Yost et al. 2006). The application of fertilizer and manures may be necessary for all the sampling locations for improved cocoa productivity (Lal 2000; Wade and Sanchez 1983). Similarly, the average content of exchangeable Ca was relatively far higher than $\mathrm{K}$ with mean values ranging from 0.7 to $2.9 \mathrm{mg} / \mathrm{kg}$. Highest concentration was recorded at Ago Panu and Ikpenme farm. Comparatively, it can be observed that the concentrations of Mg are some folds higher than those of K (Table 2). The implication of this according to Soil Survey Laboratory Staff (1992) is that the ions, K, can easily be replaced by contaminants such as heavy metals because the sorption capacities for such ions in the soil matrix are very low. It is however important to note that in studies of cations, different chemical and procedures are used to extract cations in soils $\left(\mathrm{NH}_{4}{ }^{+}\right.$acetate, acetic/lactic acids and Olsen procedures e.t.c). Thus wide variations in the levels of cations in soil are expected from different extraction techniques, resulting in different interpretations.

For Ago-panu and Ikpemu, though high in exchangeable cation, the OC are very low compared to other locations in the study. Site evaluation during sampling revealed very poor cocoa yield from these two sites, particularly at Ago-Panu. One may wonder why, considering the exchangeable cations. These ions, particularly $\mathrm{Ca}$ and $\mathrm{Mg}$ are expected considering the rocky nature of the plantation sites. However, these ions are not in bioavailable form. This can be attributed to the coarse textural and the gravelly sub- soil, which affect deep rooting and nutrients accessibility. In addition, compressibility resulting from the high proportion of silt and clay within the sites may be contributory

The low soil-CEC and low organic matter are the main constraints of fertility of these soils. Therefore, organic matter application is recommended to improve CEC, carbon content and nutrient availability particularly at Ile-Oluji, Bagbe, Govt. Farm Idanre and Oda Farm in Akure. Base saturation was high to very high (69-96\%) for all the soil profile across the various locations. These percentages are valuable indicators of the chemical richness of these locations, which will assist to determine the biological activity, the quality of its structure and reserves of nutrient elements.

In general, from available records from Ondo State Ministry of Agriculture, details of cocoa yield and ranking between 2003 and 2007 are presented in Fig.4. From Fig.4, it is obvious that other parameters may be responsible or contributory to the quantity and quality of cocoa than those considered in the study.

\subsection{Conclusion and Recommendation}

Based on the findings above, it is obvious that the dominant limiting factors of soil fertility include low organic matter content, low exchangeable minerals nutrients such as $\mathrm{K}$ and low soil CEC. Consequently, cocoa farmers are advised to increase organic matter for better soil CEC, and water holding capacity. This may include addition of farmyard manure, green manures, and/or crop residues and inorganic fertilizers.

\section{Acknowledgement}

We want to express our gratitude to the National Space Research and Development Agency (NASRDA), Nigeria, for funding this project. The authors are also grateful to the official of the Ministry of Agriculture, Ondo State, for logistic support.

\section{References}

Adegeye, A.J. (1996). Production and marketing of cocoa in Nigeria, problem and solution. In Proceeding of National seminar on Revolutionizing Nigeria's cocoa Industry, Ibadan, Nigeria. 
Adiningsih J.S., \& Sudjadi, M. (1983). Pengaruh penggenangan dan pemupukan terhadap tanah Podsolik Lampung Tengah. Pemberitaan Penelitian Tanah dan Pupuk, 2, 1-8.

Ajobo, O. (1980). Economic of cocoa production. In: Production of cocoa, coffee and tea in Nigeria. The Cocoa Board, Cocoa House, Ibadan, Nigeria. pp. 137-140.

Bouyoucos, G.J. (1962). Estimation of Colloidal Material in Soils. Science, 64, 632.

Central Bank of Nigeria (CBN), (1998). Annual report and statement of accounts for the year 1998. Central Bank of Nigeria. pp. 7-9.

Egbe, N.E. (1989). Soils and nutrition problems of cocoa, coffee, cashew and tea. In: Tree Crop Research, $2^{\text {nd }}$ Edn, Cocoa Research Institute, pp. 28 - 38.

Ekanade, O. (1985a). The Impact of Cocoa Cultivation on Soil Properties in South Western Nigeria. Unpublished Ph.D Thesis, University of Ife, pp. 305.

Ekanade, O (1985b). The Effect of Cocoa Cultivation on Some Physical Properties of the Soil in Southwestern Nigeria. The International Tree Crops Journal, 3, 113-124.

Ekanade, O. (1988). The Nutrient Status of Soils under Peasant Cocoa Farms of Varying Ages in Southwestern Nigeria. Biological Agricultural and Horticulture, 5, 155 - 167.

Hartemink, A.E. (2006). Soil Fertility Decline: Definitions and Assessment. Encyclopedia of Soil Science, pp. $1618-1621$.

Karageorgis, A.P., Anagnostou, C.L., \& Kaberi, D. (2005). Geochemistry and mineralogy of the NW Aegean Sea surface sediments: Implications for river runoff and anthropogenic impact. Applied Geochemistry, 20, 69-88.

Kershaw, K.A. (1985). Quantitaitve and Dynamic Plant Ecology, Edward Arnold. London.

Lal, R. (1989). Land Degradation and Its Impact on Food and Other Resources; Food and Natural Resources, 85-140.

Lal, R. (2000). Soil management in the developing countries. Soil Science, 165, 57-72.

Nelson, D.W., \& Sommers, L.E. (1996). Total carbon, organic carbon and organic matter. p. 961-1010. In D.L. Sparks (Eds.) Methods of soil analysis. Part 3. Chemical methods. SSSA Book Ser. 5. SSSA, Madison, WI.

Olujide, M.G., \& Adeogun, S.O. (2006). Assessment of cocoa growers' farm management practices in Ondo State, Nigeria. Spanish Journal of Agricultural Research, 4(2), 173-179.

Omotoso, T.I. (1965). Boron nutrition problems of In: Proceeding V International Cocoa Research Conference, Ibadan, Nigeria. pp. 312-315.

Omotoso, T.I. (1971). Soil aspect of cocoa rehabilitation in Nigeria. In: Cocoa Research Institute of Nigeria (CRIN) Annual Report, 1971/72.

Sanchez, P.A. (1976). Properties and management of soils in the tropics. John Willey and Sons. New York. pp. 618.

Sanchez, P.A. (2002). Soil fertility and hunger in Africa. Science, 295, 2019-2020.

Smyth, A.I., \& Montgonery, R.F. (1962). Soil and land use in central Nigeria. Government Printer, Ibadan, Western Nigeria.

Soil Survey Laboratory Staff. (1992). Soil survey laboratory methods manual. Soil Survey Investigation Report No. 41. Version 1.0. USDA, Washington DC.

State of Nigeria. In: Production of cocoa, coffee and tea in Nigeria. The Nigeria Cocoa Board, Cocoa House, Ibadan, Nigeria. pp. 93-102.

Thomas, G.W. (1982). Exchangeable cations. In A.L. Page et al. (2nd Edn.) methods of soil analysis, Agronomical Monographs. 9. ASA and SSSA, Madison, WI. pp. 159-164

Tisdale, S.L., \& Nelson, W.L. (1975). Soil fertility and fertilizers. Longman.

Wade, M.K., Sanchez, P.A (1983). Mulching and green manure application for continuous crop production in the Amazon basin. Agron. J. 75: 39-45.

Yost, R., \& Attanandana, A., \& Tasnee. E. (2006). Predicting and testing site-specific potassium fertilization of maize in soils of the tropics - an example from Thailand. Soil Science, 171, 968-980. 
Table 1. Locations/Descriptive Features of Sampling Sites

\begin{tabular}{|c|c|c|c|c|c|c|c|c|}
\hline $\begin{array}{l}\text { Sampling } \\
\text { Locations }\end{array}$ & $\begin{array}{c}\text { Local } \\
\text { Government }\end{array}$ & & ints & Met & corologic: & & & Biological \\
\hline & & Eastings & Northings & Temp. ${ }^{\circ} \mathrm{C}$ & $\begin{array}{c}\text { Rainfall } \\
\text { (mm) }\end{array}$ & $\begin{array}{c}\text { Height } \\
\text { (m) }\end{array}$ & $\begin{array}{l}\text { Farming } \\
\text { Method } \\
\end{array}$ & Challenges \\
\hline lkpemen & Owo & 786974 & 802260.1 & 29.85 & 3.93 & 287.5 & $\mathrm{H} / \mathrm{SL}$ & Procurement of inputs \\
\hline Ago-Panu & $\begin{array}{c}\text { Owo } \\
\text { Ile-Oluji/ }\end{array}$ & 788966 & 806436.5 & 29.85 & 3.93 & 260.3 & $\mathrm{H} / \mathrm{SL}$ & Dry cocoa stands, no nursery, anthill, squirrel \\
\hline Ile-Oluji & Oke-Igbo & 705658 & 792032.6 & 31.68 & 4.86 & 253.3 & $\mathrm{H} / \mathrm{SL}$ & No information \\
\hline Idanre & Idanre & 737410 & 793852.0 & 32,13 & 3.54 & 297,6 & $\mathrm{H} / \mathrm{SL}$ & Mistletoe on trees and other epiphytes \\
\hline Oda-Akure & Akure South & 748307 & 792318.7 & 33.09 & 4.57 & 324.6 & $\mathrm{H} / \mathrm{SL}$ & Squirrel, epiphytes on trees \\
\hline Bagbe-Ondo & Ondo West & 704188 & 771096.6 & 32.5 & 6.56 & 227,2 & $\mathrm{H} / \mathrm{SL}$ & Anthill, squirrel, stealing, bush burning \\
\hline
\end{tabular}

\section{H/SL: Hiring/sharing labourers}

Table 2. Ranges $(n=3)$ and Mean Concentrations (meq/100g) of Soil Physicochemical Characteristics

\begin{tabular}{|c|c|c|c|c|c|c|c|c|c|}
\hline Communities & $\begin{array}{l}\text { Soil } \\
\text { Layers }\end{array}$ & pH & OC (\%) & $\mathrm{Ca}^{*}$ & Mg* & $\mathrm{Na}^{*}$ & $\mathbf{K}^{*}$ & Exc. $A^{*}$ & $\mathbf{B} / \mathbf{S}$ \\
\hline \multirow[t]{3}{*}{ Ikpenme-Owo } & $0-15$ & $6.99-7.50$ & $1.42-1.75$ & 2.5 & 1.7 & 0.21 & 0.43 & 1.09 & 0.81 \\
\hline & $15-30$ & $6.57-6.88$ & $0.76-1.03$ & 2.5 & 1.8 & 0.24 & 0.28 & 0.24 & 0.70 \\
\hline & $30-45$ & $6.23-685$ & $0.35-0.65$ & 2.4 & 2.2 & 0.22 & 0.33 & 0.44 & 0.86 \\
\hline \multirow[t]{3}{*}{ Ago Panu-Owo } & $0-15$ & $6.28-6.97$ & $1.65-1.88$ & 1.2 & 0.9 & 0.23 & 0.23 & 1.38 & 0.75 \\
\hline & $15-30$ & $6.29-6.56$ & $1.21-1.37$ & 2.0 & 1.1 & 0.23 & 0.17 & 1.52 & 0.83 \\
\hline & $30-45$ & $5.99-6.46$ & $0.34-1.17$ & 2.9 & 2.1 & 0.22 & 0.20 & 0.67 & 0.90 \\
\hline \multirow[t]{3}{*}{ Ile-Oluji } & $0-15$ & $5.08-5.23$ & $2.72-3.14$ & 1.7 & 1.3 & 0.21 & 0.24 & 0.77 & 0.82 \\
\hline & $15-30$ & $5.11-5.51$ & $1.31-1.82$ & 1.4 & 1.1 & 0.23 & 0.22 & 0.19 & 0.94 \\
\hline & $30-45$ & $5.28-5.64$ & $1.16-1.28$ & 1.3 & 0.8 & 0.14 & 0.17 & 0.09 & 0.96 \\
\hline \multirow[t]{3}{*}{ Bagbe-Ondo } & $0-15$ & $5.95-6.77$ & $2.96-3.47$ & 1.8 & 1.2 & 0.22 & 0.33 & 0.11 & 0.65 \\
\hline & $15-30$ & $5.41-6.73$ & $2.00-2.48$ & 1.5 & 0.9 & 0.14 & 0.18 & 0.47 & 0.86 \\
\hline & $30-45$ & $5.24-5.60$ & $1.52-2.20$ & 1.3 & 0.8 & 0.13 & 0.22 & 0.33 & 0.87 \\
\hline \multirow[t]{3}{*}{ Govt. Farm-Idanre } & $0-15$ & $6.29-7.03$ & $3.68-4.30$ & 1.8 & 1.3 & 0.19 & 0.25 & 1.60 & 0.69 \\
\hline & $15-30$ & $6.49-6.89$ & $1.03-1.69$ & 0.7 & 1.02 & 0.17 & 0.22 & 0.32 & 0.96 \\
\hline & $30-45$ & $6.42-6.66$ & $0.86-1.52$ & 1.2 & 0.8 & 0.17 & 0.12 & 0.24 & 0.88 \\
\hline \multirow[t]{3}{*}{ Oda-Akure } & $0-15$ & $6.06-6.50$ & $3.71-3.78$ & 2.1 & 1.0 & 0.21 & 0.38 & 1.47 & 0.72 \\
\hline & $15-30$ & $5.91-6.63$ & $1.02-1.62$ & 1.2 & 0.7 & 0.22 & 0.23 & 0.41 & 0.84 \\
\hline & $30-45$ & $6.19-6.69$ & $1.14-1.82$ & 1.3 & 1.0 & 0.15 & 0.23 & 0.61 & 0.82 \\
\hline
\end{tabular}

*Values are means of three replicates; Exc.A: Exchangeable acidity; B/S: Base saturation

Table 3. Yield Data (Ranking) of Cocoa in Ondo State Between 2003 - 2007*.

\begin{tabular}{|c|c|c|c|c|c|c|c|}
\hline SN & Location & Local Government & $2003(\mathrm{MT})$ & 2004 (MT) & $2005(\mathrm{MT})$ & $2006(\mathrm{MT})$ & 2007 (MT) \\
\hline 1 & Ikpemen & Owo & $3491^{\mathrm{E}}$ & $5543^{\mathrm{D}}$ & $4056^{\mathrm{D}}$ & $5083^{\mathrm{D}}$ & $3745.5^{\mathrm{D}}$ \\
\hline 2 & Ago $\cdot$ Panu & Owo & $3491^{\mathrm{E}}$ & $5543^{\mathrm{D}}$ & $4056^{\mathrm{D}}$ & $5083^{\mathrm{D}}$ & $3745.5^{\mathrm{D}}$ \\
\hline 3 & Ile-Oluji & Ile-Oluji/Oke-Igbo & $4661^{\mathrm{D}}$ & $4873.5^{\mathrm{E}}$ & $3682^{\mathrm{E}}$ & $4211^{\mathrm{E}}$ & $4152^{\mathrm{C}}$ \\
\hline 4 & Idanre & Idanre & $14703.5^{\wedge}$ & $15419^{\wedge}$ & $14334.5^{\wedge}$ & $17015^{\wedge}$ & $11306^{\wedge}$ \\
\hline 5 & Oda-Akure & Akure South & $6024^{C}$ & $7997.5^{\mathrm{C}}$ & $7862.5^{\mathrm{C}}$ & $5116^{\mathrm{C}}$ & $3706.5^{\mathrm{E}}$ \\
\hline 6 & Bagbe-Ondo & Ondo West & $13669.5^{\mathrm{B}}$ & $12023^{\mathrm{B}}$ & $8986.5^{\mathrm{B}}$ & $12287^{\mathrm{B}}$ & $8563.5^{\mathrm{B}}$ \\
\hline
\end{tabular}

"Data from Ondo State Ministry of Agriculture, Nigera. MT: Metric tonne.

Ranking Order: $1^{\text {st }}=A, 2^{\text {nd }}=B 3^{\text {nd }}=C, 4^{\text {th }}=D, 5^{\text {th }}=\mathrm{E}$ 


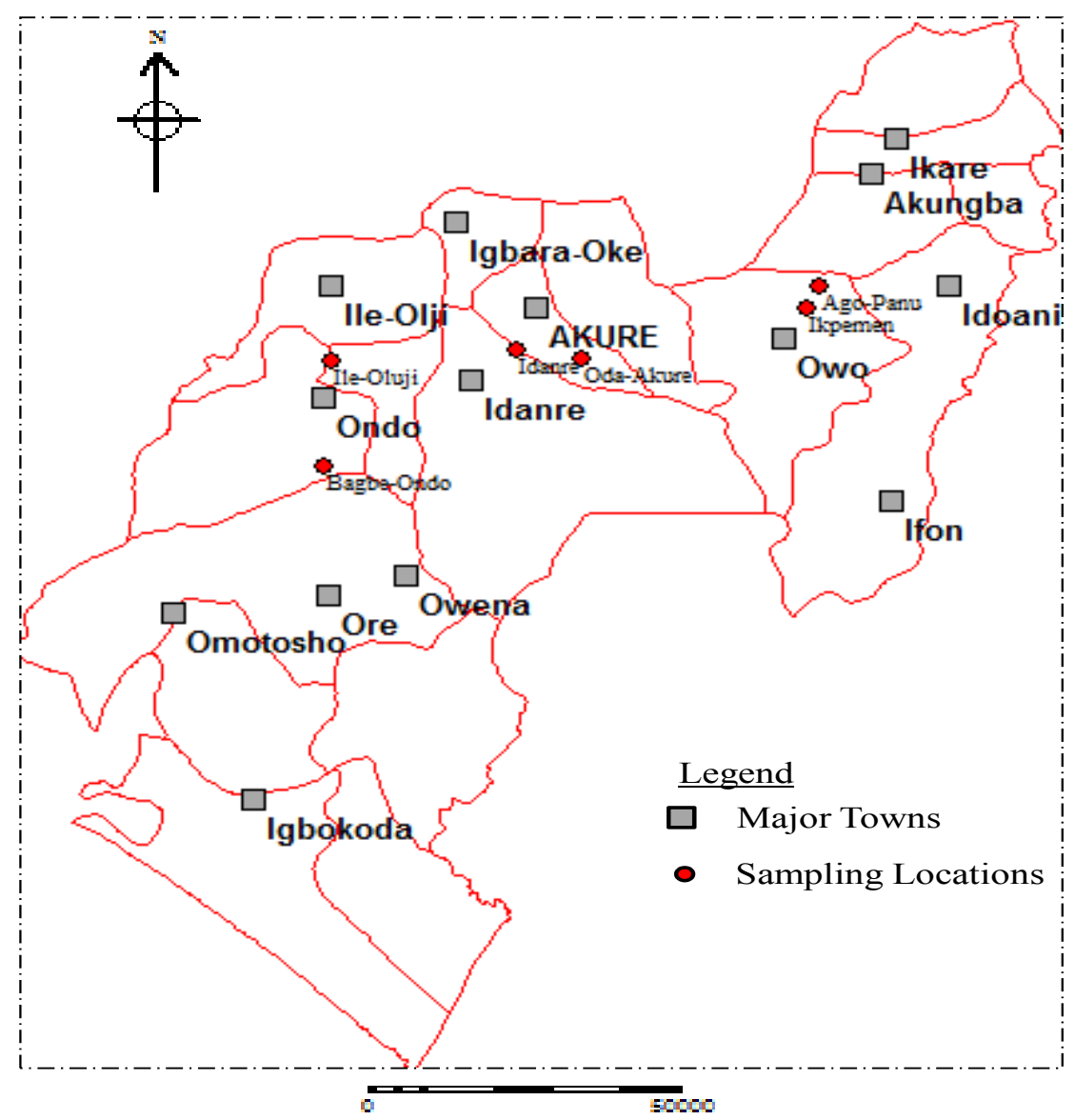

Fig 1: Area map of sampling locations

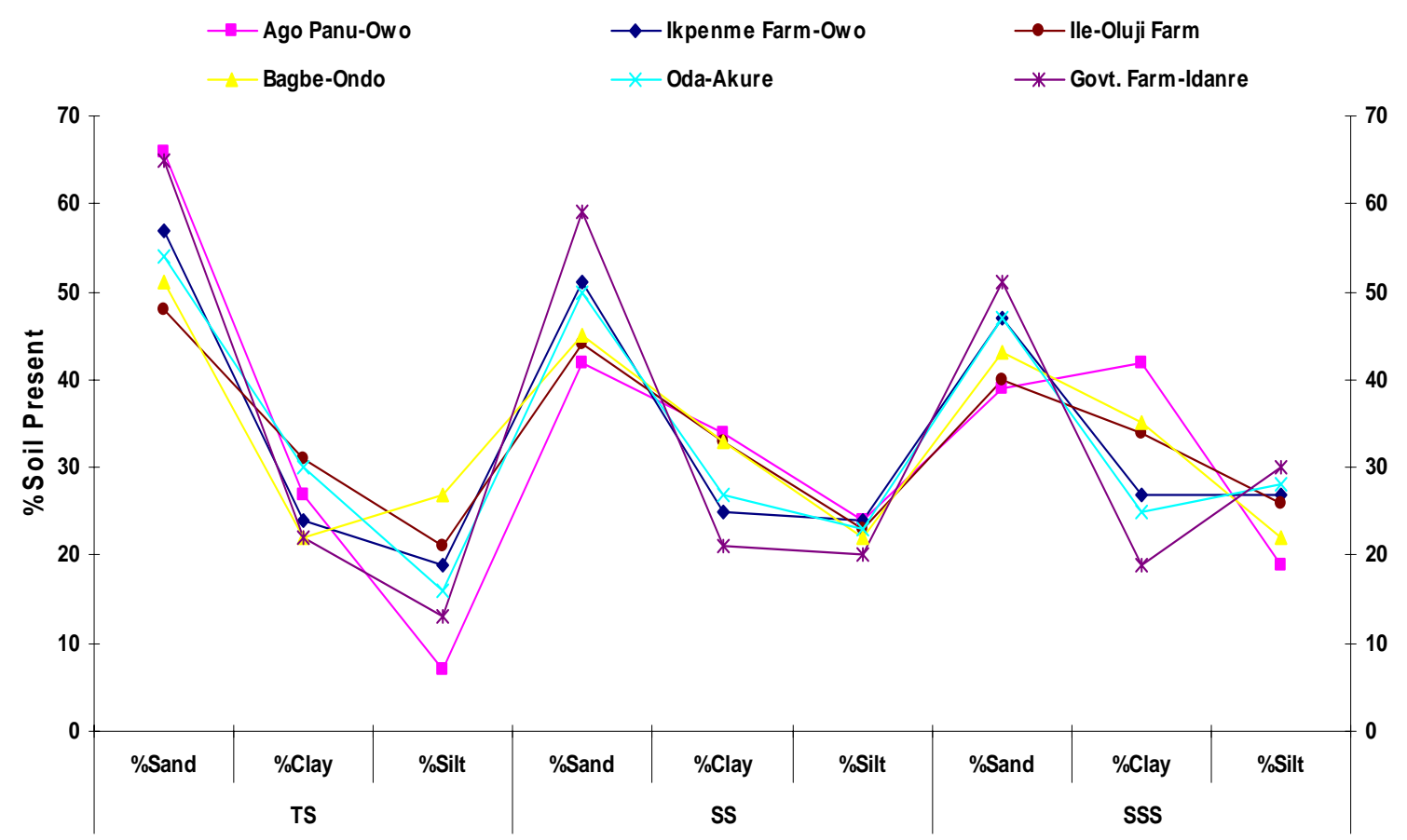

Figure 2. Percent sand, clay and silt versus depth profile across study areas 


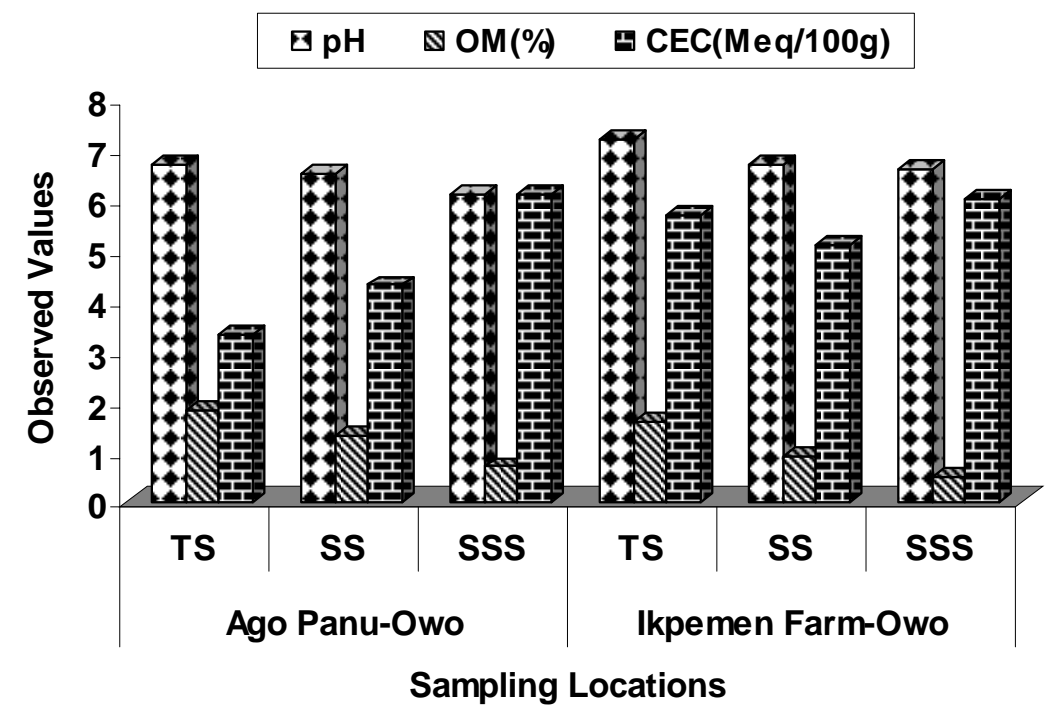

Figure 3a. Distribution pattern of soil physico-chemical across Ago-Panu and Ikpenme Farm-Owo

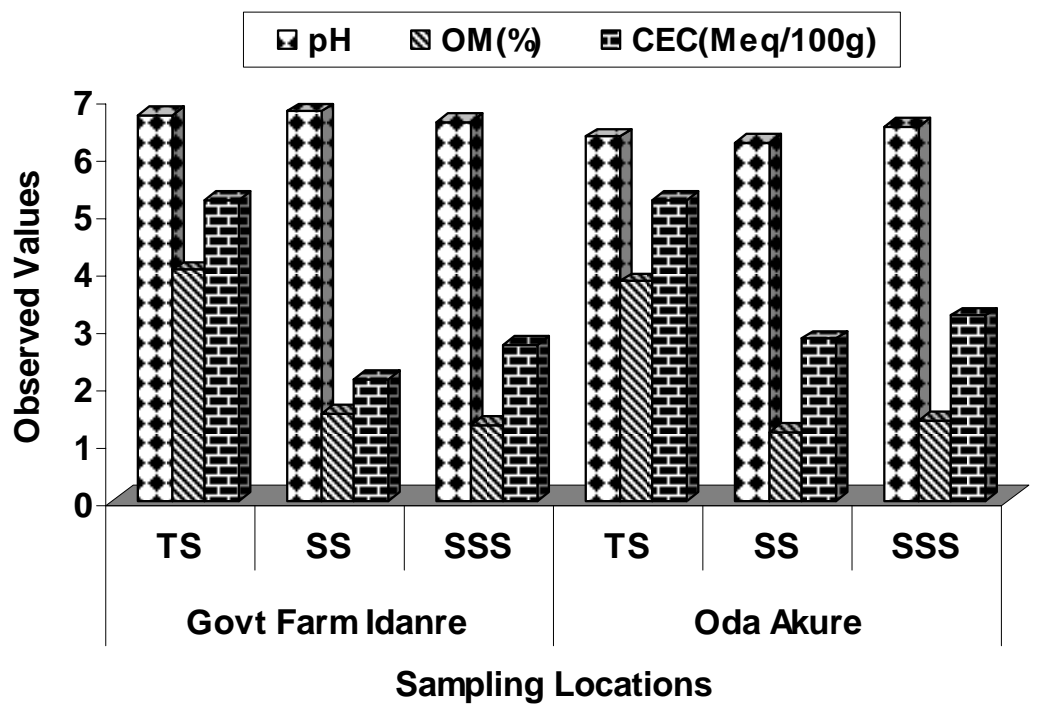

Figure 3b. Distribution pattern of soil physico-chemical across Govt. Farm Idanre and Oda Akure 


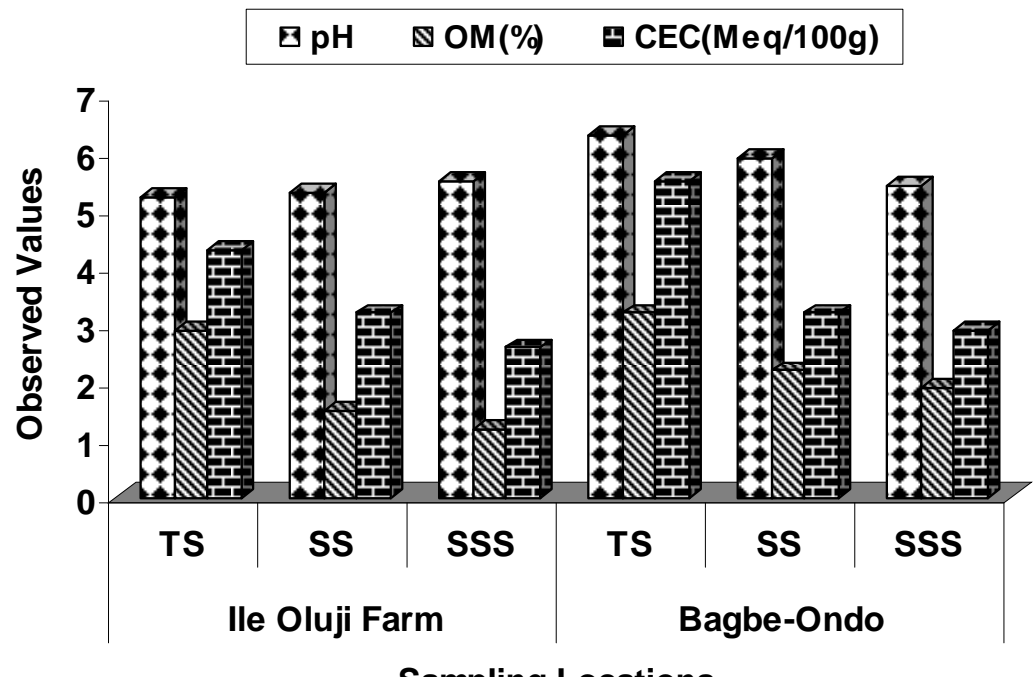

Sampling Locations

Figure 3c. Distribution pattern of soil physico-chemical across Ile-Oluji Farm and Bagbe

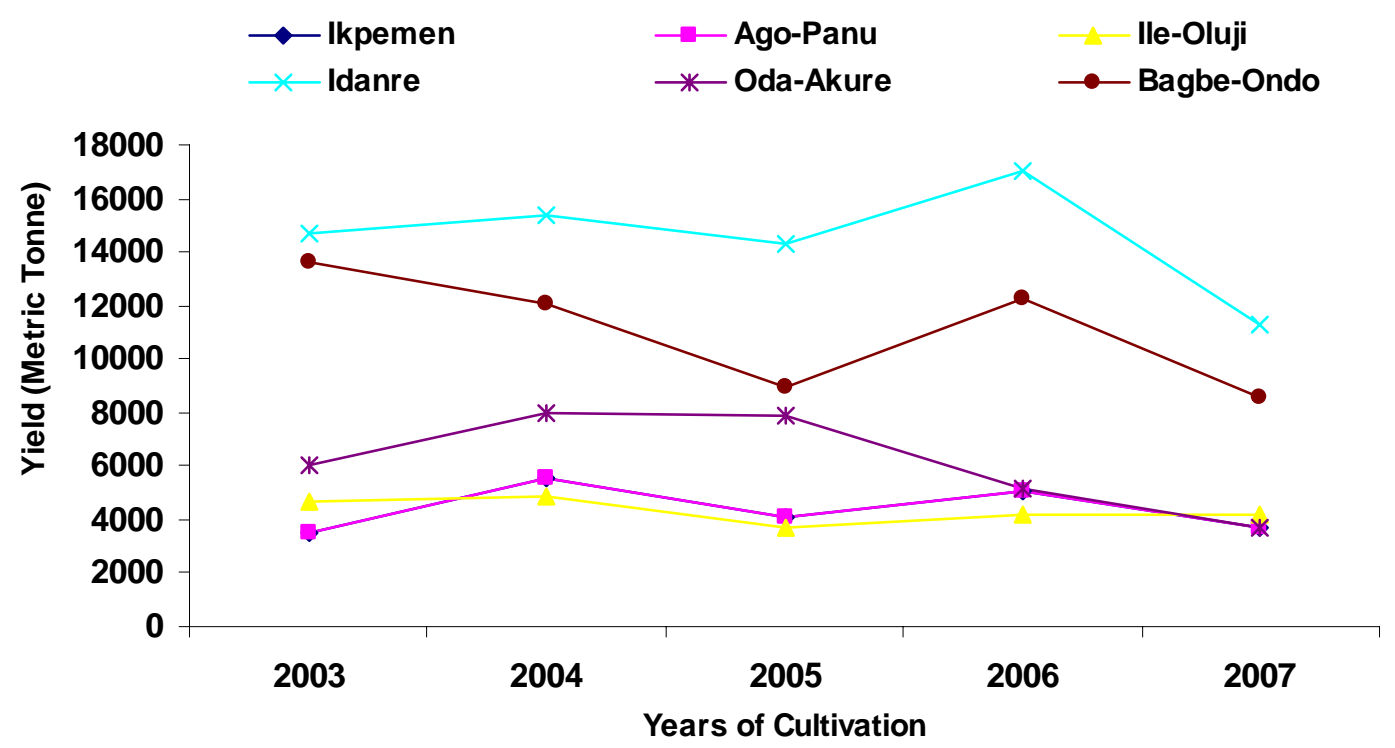

Figure 4. Yield Data of Cocoa in Ondo State Between 2003 - 2007*.

*Data from Ondo State Ministry of Agriculture, Nigera. 